\title{
Modeling of discharges from the breeding basins of rainbow trout fed with three extruded feeds (B, F1, and F2)
}

\author{
Khadija Ouaissa ${ }^{1,2, *}$, Assia Kritihi ${ }^{1,2}$, Youness Oumessoud, Abdel Aziz Maychal' ${ }^{2}$, and Mustapha Hasnaoui ${ }^{1}$ \\ ${ }^{1}$ Environnemental engineering Team. Department of Biology, Faculty of Sciences and Techniques .University Sultan MoulaySlimane. \\ M' Ghila, B.O 523. 23000 Beni-Mellal, Morocco \\ ${ }^{2}$ Fish Farming Ain Aghbal, Azrou-Morocco
}

\begin{abstract}
The main of this study is to estimate the maximum density of fish in the growing basins of rainbow trout (Oncorhynkiss Mykiss) species by mathematical equations, which will be used to introduce environmental concerns. Indeed, these equations make it possible to estimate the maximum density of fish fed by the extruded feed B and the two elaborated exruded feeds (F1 and F2) to achieve an optimal production without harming the environment. Note that the elements (PO43-, NH4 +, NO2-, NO3-, SM, COD) were analyzed during the rainbow trout grow-out test in the breeding station of 'Oum Er rbia. According to the results of density modeling as a function of physicochemical parameters, production can increase up to a density of $\rho \mathrm{F} 2=237.09 \mathrm{Kg} / \mathrm{m} 3$ without affecting the quality of the water while respecting the required standards. Our results show that the $\mathrm{F} 2$ formulation, containing $60 \%$ protein of animal origin and $40 \%$ of vegetable protein gives great zootechnical growth of rainbow trout with a low production of fish waste.
\end{abstract}

\section{Introduction}

In recent years, intensive aquaculture has been the subject of various questions concerning impacts on the aquatic environment, in particular because of nitrogen and phosphorus discharges, elements that favor the proliferation of algae. However, phosphorus $(\mathrm{P})$ is one of essential element for growth fish, especially as a component of skeleton.

In fish farming, the phosphorus discharges obtained from feed (source of $\mathrm{P}$ ) not ingested or $\mathrm{P}$ which exceeds the physiological needs of the fish which is then evacuated in both urine and faces [1].

Intensified intensive aquaculture generates in the environment a phosphorus load about $7 \mathrm{~kg}$ per ton of fish produced, which can cause and accelerate the aging of the receiving water body [1].

The negative impact of phosphorus on the environment led to a tightening of discharge standards and slowed the expansion of aquaculture in several countries, especially industrialized, thus depriving the population of the positive aspects of aquaculture [1-3].

Unlike terrestrial farms whose emissions into the aquatic environment pass through the soil filter, the discharges from fish farming are direct and the impacts more easily identifiable. This characteristic partly explains the attention paid to them. However, the contribution of fish-originated fish discharges to environmental pollution is limited since fish farming consumes $0.5 \%$ of all feed and that fish is an efficient feed processor, with conversion indices close to one in trout [4]. To improve environmental integration in fish farming, it is therefore necessary to both describe, assess and understand the impacts, then find ways to reduce them. A first step is to set a baseline on the state of the environment to monitor its development and the potential impacts of activities. In this context, beyond the physico-chemical analyzes, the approaches developed on the diversity of biological stands are interesting because they offer the impacts in terms of ecosystem functioning, the management of pollutant discharges from fish farming requires the use of operational simulation and modeling tools enabling the reduction of releases at source thanks to an improvement in production efficiency.

\section{Material and methods}

\subsection{Geographical location}

The breeding station of Oum Er-Rbia, commonly called Oued aux 40 sources. Located on the left bank of the river Oum Er-Rbia, these sources feded by water crossing salt fields. However, this water, although salty, does not have the same composition as seawater with the absence of iodine and other salts. This station has a breeding capacity of $600 \mathrm{~m}^{3}$ and a production capacity of 130 tonnes / year. Of them, separate water pipes serving freshwater and saltwater basins.

\footnotetext{
* Corresponding author: khadijaouaissa89@gmail.com
} 


\subsection{Test basins}

Although our study was confronted with technical modalities linked to the operation of the Oum Er-Rbia station, we chosen 4 polystyrene basins of square shape (BCA, BCB, BCC and BCD) with a volume of $8 \mathrm{~m}^{3}$.

The debt water flow (Oum Er-Rbia spring water) is $11.47 \mathrm{~m}^{3} / \mathrm{h}$ at the entrance of the 4 basins. This test is carried out under the same conditions as those of the comparative test of feeds $\mathrm{A}, \mathrm{B}$ and $\mathrm{C}$.

The water renewal time is the same level for all the basins.

The test is carried out in monoculture; the fish were fed in the main with a very precise daily ration according to the number of fish and the biomass. The ration was split into two meals distributed at 8 a.m. and 2 p.m. An elaborate type of formulation (F1 and F2) feeds two basins.

The physical parameters analyzed in situ are water temperature, $\mathrm{pH}$, and electrical conductivity and dissolved oxygen.

The chemical analyzes of the water were carried out upstream and downstream of the four test basins (BCA, $\mathrm{BCB}, \mathrm{BCC}, \mathrm{BCD})$.

To estimate the concentrations of ammoniacal nitrogen, nitrites, nitrates, orthophosphates, suspended solids and the chemical oxygen demand at the outlet of the basins, 5 water samples were taken every two months.

\subsection{Biochimical composition of three feeds( F1, $\mathrm{F} 2$, and F3).}

Table 1. Biochimical analyzes of two formula

\begin{tabular}{|l|c|c|c|}
\hline & $\begin{array}{c}\text { Formulation } \\
\mathbf{1}\end{array}$ & $\begin{array}{c}\text { Formulation } \\
\mathbf{2}\end{array}$ & $\begin{array}{c}\text { Feed } \\
\mathbf{B}\end{array}$ \\
\hline Humidity (\%) & $10 \%$ & 4,2 & 10 \\
\hline Ashes (\%) & 7,12 & 7,2 & 7,2 \\
\hline $\begin{array}{l}\text { Protein } \\
* 6,25 \%\end{array}$ & 41,35 & 39,3 & 41 \\
\hline Fat (\%) & 24,25 & 21,10 & 24 \\
\hline $\begin{array}{l}\text { Carbohydrates } \\
(\%)\end{array}$ & 21,24 & 19,5 & 20,5 \\
\hline $\begin{array}{l}\text { Total Phosphus } \\
(\%)\end{array}$ & 0,93 & 0,95 & 1 \\
\hline $\begin{array}{l}\text { Totales fibres } \\
(\%)\end{array}$ & 2,38 & 2,20 & 2,3 \\
\hline $\begin{array}{l}\text { Energy value } \\
(\mathrm{Mj} / \mathrm{kg})\end{array}$ & 21,31 & 20,44 & 21,92 \\
\hline
\end{tabular}

Analysis of the two formulations developed for the study verified their actual compositions. Different parameters (humidity, ash content, crude protein content, crude fat content, phosphorus and energy content) were analyzed for each feed protein, fat, and energy levels remained within reasonable limits of feed B values.

\section{Results}

During our experimental trial where the growth cycle of rainbow trout during the fattening phase (500-1000g) lasted only 43 days, the four water samples taken for physical analysis were insufficient to correlate the density data and the fish discards, which led us to estimate the biomass in order to correlate the data.

Reading table 2, F2 is the formulation which exhibits the large growth (1207.26 g) for a period of 50 days (500-1000g = fattening phase) with a weight difference of $163.41 \mathrm{~g}$ compared to feed B.

Table 2. Rainbow trout growth according to the three foods (B, $\mathrm{F} 1$, and F2)

\begin{tabular}{|l|c|c|c|}
\hline \multicolumn{1}{|c|}{ Parameters } & Feed B & Formula 1 & Formula 2 \\
\hline initial weight (g) & 580,7 & 577,6 & 578 \\
\hline $\begin{array}{l}\text { Final } \\
\text { weight (g) }\end{array}$ & 1043,9 & 988 & 1080 \\
\hline $\begin{array}{l}\text { Weight } \\
\text { gain (g) }\end{array}$ & 463,2 & 410,4 & 502 \\
\hline $\begin{array}{l}\text { Number } \\
\text { of days }\end{array}$ & 50 & 43 & 43 \\
\hline $\begin{array}{l}\text { Specific growth } \\
\text { index \% }\end{array}$ & 1,6 & 1,6 & 2 \\
\hline $\begin{array}{l}\text { Survival index } \\
\text { (\%) }\end{array}$ & 99,65 & 98,83 & 92,17 \\
\hline Conversion index & 0,90 & 0,82 & 0,73 \\
\hline Condition factor & 1,60 & 1,14 & 1,72 \\
\hline
\end{tabular}

The two formulas developed were well accepted by the fish during the test with a water temperature ranging from 13.9 to $14.1^{\circ} \mathrm{C}$. At the end of the experimental test, the data show that the variation in the performance of the zootechnical parameters is significant $(p<0.05)$ between the two formulas because the final weights of the fish are between $\mathrm{F} 1=988 \mathrm{~g}$ and F2 $=1080 \mathrm{~g}$ and Tukey's test shows that there is a significant difference between the two final weights $(\mathrm{p}<0.05)$. The percentage weight gain is 463.2 for reference feed $\mathrm{B}$, while it is 410.2 and 502 for F1 and F2 respectively. Statistical analysis showed that there is not a significant difference between these two values of the two diets $(\mathrm{p}>0.05)$. The calculated specific growth rates vary between $1.6 \%$ in fish fed with diet B with $1.6 \%$ for $\mathrm{F} 1$ and $2 \%$ in fish fed with formula $\mathrm{F} 2$. This statistical test shows that there is a significant difference with $(\mathrm{p}<0.05)$. The results for the condition factor showed a significant difference $(\mathrm{p}<0.05)$ between the three regimens (B, F1 and F2). In addition, F2 has an excellent condition factor $(\mathrm{Kb}=1.72)$ compared to feed B.

The food conversion of the fish subjected to the different diets show that the formula F2 is as effective as the compared diet $\mathrm{B}$ since the best feed conversion rate observed is present for the diet of the formula F2 with an average of $\mathrm{IC}_{\mathrm{F} 2}=0.73$.

The estimation of the maximum production density of rainbow trout is carried out by a correlation between the density and the physicochemical elements studied $\left(\mathrm{PO}_{4}{ }^{3-}, \mathrm{NH}_{4}{ }^{+}, \mathrm{NO}_{2}{ }^{-}, \mathrm{NO}_{3}{ }^{-}, \mathrm{SM}\right.$ and $\left.\mathrm{COD}\right)$ for the three feeds B, F1 and F2.

\subsection{Diet B}

The physicochemical parameters were modeled by mathematical equations according to the points of 
correlation between the density and the parameter in question. For feed $\mathrm{B}$, the maximum production density determined is $\rho_{\mathrm{B}}=176.35 \mathrm{Kg} / \mathrm{m}^{3}$.

Table 3. Modeling by mathematical equations for rejections of $\operatorname{diet} \mathrm{B}$

\begin{tabular}{|c|c|c|}
\hline \multicolumn{3}{|c|}{ Feed B } \\
\hline $\begin{array}{c}\text { Physico- } \\
\text { chemicalelements }\end{array}$ & Mathematicalfunctions & $\begin{array}{c}\text { Maximum } \\
\text { density }\end{array}$ \\
\hline $\mathrm{PO}_{4}^{3-}$ & $\begin{array}{c}\mathrm{Y}=0,073 \mathrm{e} 0,012 \mathrm{x} \\
\text { avec } \mathrm{R} 2=0,903\end{array}$ & $\begin{array}{l}\rho=160 \\
\mathrm{Kg} / \mathrm{m}^{3}\end{array}$ \\
\hline $\mathrm{NH}_{4}^{+}$ & $\begin{array}{c}\mathrm{Y}=0,111 \mathrm{e} 0,027 \mathrm{x} \text { avec } \\
\mathrm{R}^{2}=0,985\end{array}$ & $\begin{array}{c}\rho=55,74 \\
\mathrm{Kg} / \mathrm{m}^{3}\end{array}$ \\
\hline $\mathrm{NO}_{2}^{-}$ & $\begin{array}{c}\mathrm{Y}=0,012 \mathrm{e} 0,032 \mathrm{x} \text { avec } \\
\mathrm{R}^{2}=0,929\end{array}$ & $\begin{array}{l}\rho=100 \\
\mathrm{Kg} / \mathrm{m}^{3}\end{array}$ \\
\hline $\mathrm{NO}_{3}^{-}$ & $\begin{array}{l}Y=0,019 \times 2-0,778 x+ \\
13,93 \text { avec } R^{2}=0,812\end{array}$ & $\begin{array}{c}\rho=108,53 \\
\mathrm{Kg} / \mathrm{m}^{3}\end{array}$ \\
\hline SM & $\begin{array}{l}Y=0,010 \times 2-0,440 x+ \\
14,06 \text { avec } R^{2}=0,988\end{array}$ & $\begin{array}{c}\rho=176,35 \\
\mathrm{Kg} / \mathrm{m}^{3}\end{array}$ \\
\hline COD & $\begin{array}{c}\mathrm{Y}=18,92 \mathrm{e} 0,010 \mathrm{x} \text { avec } \\
\mathrm{R}^{2}=0,874\end{array}$ & $\begin{array}{c}\rho=144,78 \\
\mathrm{Kg} / \mathrm{m}^{3}\end{array}$ \\
\hline
\end{tabular}

According to the results of table 3 , the maximum densities for feed $\mathrm{B}$ and the elaborate regimes F1 and F2 generate discharges not exceeding the environmental standards for all the elements analyzed, thus the discharges from the two regimes F1 and F1 are very low compared to the standards of fish discharges.

\subsubsection{Elaborated feed F1}

Each parameter is modeled by a mathematical equation according to the correlation points between the density and the evaluated parameter. For formula F1, the maximum production density is $\rho \mathrm{F} 1=175 \mathrm{Kg} / \mathrm{m}^{3}$.

Table 4. Modeling by mathematical equations for rejections of feed $\mathrm{F} 1$

\begin{tabular}{|c|c|c|}
\hline \multicolumn{3}{|c|}{ Formulation 1} \\
\hline $\begin{array}{l}\text { Physico- } \\
\text { chemical } \\
\text { elements }\end{array}$ & Mathematical functions & $\begin{array}{l}\text { Maximum } \\
\text { density }\end{array}$ \\
\hline $\mathrm{PO}_{4}{ }^{3-}$ & $\begin{array}{c}\mathrm{Y}=0,010 \mathrm{e} 0,052 \mathrm{x} \text { avec } \mathrm{R}^{2}= \\
0,958\end{array}$ & $\rho=75.33 \mathrm{Kg} / \mathrm{m}^{3}$ \\
\hline $\mathrm{NH}_{4}^{+}$ & $\begin{array}{c}\mathrm{Y}=0,111 \mathrm{e} 0,027 \mathrm{x} \text { avec } \mathrm{R}^{2}= \\
0,985\end{array}$ & $\rho=55,74 \mathrm{Kg} / \mathrm{m}^{3}$ \\
\hline $\mathrm{NO}_{2}^{-}$ & $\begin{array}{c}\mathrm{Y}=-3 \mathrm{E}-05 \mathrm{x} 2+0,003 \mathrm{x}- \\
0,049 \text { avec } \mathrm{R}^{2}=0,991\end{array}$ & $\rho=175 \mathrm{Kg} / \mathrm{m}^{3}$ \\
\hline $\mathrm{NO}_{3}^{-}$ & $\begin{array}{c}\mathrm{Y}=0,019 \mathrm{x} 2-0,778 \mathrm{x}+ \\
13,93 \text { avec } \mathrm{R}^{2}=0,812\end{array}$ & $\begin{array}{c}\rho=130,53 \\
\mathrm{Kg} / \mathrm{m}^{3}\end{array}$ \\
\hline SM & $\begin{array}{c}\mathrm{Y}=0,620 \mathrm{e} 0,071 \mathrm{x} \text { avec } \mathrm{R}^{2}= \\
0,942\end{array}$ & $\rho=44,87 \mathrm{Kg} / \mathrm{m}^{3}$ \\
\hline COD & $\begin{array}{c}\mathrm{Y}=17,92 \mathrm{e} 0,006 \mathrm{x} \text { avec } \mathrm{R}^{2}= \\
0,972\end{array}$ & $\rho=18,30 \mathrm{Kg} / \mathrm{m}^{3}$ \\
\hline
\end{tabular}

\subsubsection{Elaborated feed F1}

Similarly, after determining the mathematical functions of each parameter, the maximum production density for feed $\mathrm{F} 2$ is greater $\rho \mathrm{F} 2=237.09 \mathrm{Kg} / \mathrm{m}^{3}$.
Table 5. Modeling by mathematical equations for rejections of feed F2

\begin{tabular}{|c|c|c|}
\hline \multicolumn{3}{|c|}{ Formulation 2} \\
\hline $\begin{array}{c}\text { Mathematical } \\
\text { functions }\end{array}$ & Mathematical functions & $\begin{array}{c}\text { Maximum } \\
\text { density }\end{array}$ \\
\hline $\mathrm{PO}_{4}{ }^{3-}$ & $\begin{array}{c}\mathrm{Y}=0,020 \mathrm{e} 0,033 \mathrm{x} \text { avec } \\
\mathrm{R}^{2}=0,978\end{array}$ & $\rho=237,09 \mathrm{Kg} / \mathrm{m}^{3}$ \\
\hline $\mathrm{NH}_{4}{ }^{+}$ & $\begin{array}{c}\mathrm{Y}=0,004 \mathrm{x}-0,106 \text { avec } \\
\mathrm{R}^{2}=0,912\end{array}$ & $\rho=151,5 \mathrm{Kg} / \mathrm{m}^{3}$ \\
\hline $\mathrm{NO}_{2}{ }^{-}$ & $\begin{array}{c}\mathrm{Y}=-6 \mathrm{E}-05 \mathrm{x} 2+0,004 \mathrm{x} \\
-0,072 \text { avec } \mathrm{R}^{2}=0,994\end{array}$ & $\rho=22,5 \mathrm{Kg} / \mathrm{m}^{3}$ \\
\hline $\mathrm{NO}_{3}{ }^{-}$ & $\begin{array}{c}\mathrm{Y}=-0,003 \times 2+0,236 \mathrm{x} \\
+1,498 \text { avec } \mathrm{R}^{2}= \\
0,999\end{array}$ & $\rho=145,5 \mathrm{Kg} / \mathrm{m}^{3}$ \\
\hline $\mathrm{SM}_{\mathrm{COD}}$ & $\begin{array}{c}\mathrm{Y}=0,257 \mathrm{x}-4,313 \text { avec } \\
\mathrm{R}^{2}=0,958\end{array}$ & $\rho=75,54 \mathrm{Kg} / \mathrm{m}^{3}$ \\
\hline $\mathrm{R}^{2}=0,911$ & $\rho=14,04 \mathrm{Kg} / \mathrm{m}^{3}$ \\
\hline
\end{tabular}

According to the results of modeling of the densities according to physicochemical parameters $\left(\mathrm{PO}_{4}{ }^{3-}, \mathrm{NH}_{4}{ }^{+}\right.$, $\mathrm{NO}_{2}^{-}, \mathrm{NO}_{3}^{-}, \mathrm{SM}$ and $\left.\mathrm{COD}\right)$, the production can increase until a density of $\rho \mathrm{F} 2=237.09 \mathrm{Kg} / \mathrm{m}^{3}$ without affecting the quality of the water while respecting the required standards.

\section{Discussion}

According to our results, the formulation which indicates high growth is $\mathrm{F} 2$, it contains $60 \%$ animal protein and 40 $\%$ of vegetal protein, the growth difference between two formulations F1 and F2 is not significant.

The main role of dietary protein is to support the maintenance and synthesis of body protein and therefore protein growth, but not all protein sources are equally effective. We must of course take into account their digestibility, but even with equal digestibility, the efficiency may vary.

Several studies carried out on the substitutions of animal protein levels higher by 30 to $50 \%$ (depending on the ingredients) lead to a decrease in growth performance [5 - 7].

This is contradictory to what was found as a result, the substitution of fish proteins by vegetable proteins with a proportion which reached $60 \%$ demonstrated a remarkable growth (295.8 g) during a duration of 43 days and a weak conversion index $[\mathrm{CI}=0.73]$. There are important differences between fish species depending on their trophic level, it is possible to incorporate varying levels of carbohydrate in feed [8]. Thus, herbivorous (grass carp) and omnivorous (common carp) species accept up to $40 \%$ of carbohydrates in their food without this modifying their growth performance, while providing beneficial elements: protein savings and a decrease in nitrogenous emissions linked to the use of glucose as an energy source.

The growth of fish obtained with two feeding methods $(\mathrm{F} 2=1080 ; \mathrm{F} 1=988 \mathrm{~g}$ during 43 days $)$ compares favorably with that obtained by [9] in an 11week feeding trial of trout with diets containing $0.6,0.9$ and $1.2 \%$ total phosphorus. 
Regarding the conversion index values obtained in the present experiment, it can be considered that the results are qualified, on the whole as good for the two formulas developed, lying within a range between 0.83 and 0.86 .

The condition factor $\mathrm{K}$, which provides information on the nutritional status of fish, is used to assess the productivity of rivers or the effect of the environment on certain reproduction parameters and the status of stocks aquatic species like the conversion index, the condition factor $\mathrm{K}$ is used to assess the nutritional performance of a diet. In this study, fish fed the F2 diet exhibited a higher $\mathrm{K}_{\mathrm{F} 2}$ factor than fish fed the other diets (F1 and $\mathrm{B}$ ).

The impact of fish farming on the aquatic environment is mainly of nutritional origin resulting from the feeding of fish.

In our study, physico-chemical analyzes were carried out for each feed. Several series of samples were taken simultaneously at the exit of the station to obtain representative results. However, the number of samples to be taken for the study of discharges from a fish farm for modeling must be sufficient to be representative [10, 11] the production of $\mathrm{PO}_{4}{ }^{3-}$ is $0.7 ; 0.8$ and $1 \mathrm{~kg}$ per tonne of fish produced respectively for feeds F1, F2 and B. The low concentration of $\mathrm{PO}_{4}{ }^{3-}$ released into the outlet water is linked to the amount of phosphate available in processed feeds (F1 and F2). Phosphorus is mainly from fish meal for F2 and corn gluten for F1. The control of the feed fish manufacturing process by extrusion is an essential parameter in the availability of phosphorus. The values recorded are much lower than those found by [12] who report that the most recent feeds only produce around $4.5 \mathrm{~kg}$ per tonne of phosphorus production from the fish produced.

A lot of work has already been done in this way of reducing discharges. According to [13] thanks to reductions of $40 \%$ in the conversion rate (from 2.08 to 1.25 ) and $59 \%$ of the phosphorus concentration in the food (from 1.7 to 0.7 ); phosphorus emissions fell from $31 \mathrm{~kg}$ per tonne of fish produced in 1974 to $4.8 \mathrm{~kg}$ per tonne in 1994 , a reduction of $85 \%$.

For ammoniacal nitrogen, the two formulations F1 and F2 reject a small amount of $0.4 \mathrm{~kg}$ and $0.1 \mathrm{~kg}$ of nitrogenous rejections per tonne of fish produced compared to food B that emits $3 \mathrm{~kg}$ per tonne.

For suspended solids, 80 and $60 \mathrm{~kg} /$ tonne of fish produced are rejected respectively for $\mathrm{F} 1$ and $\mathrm{F} 2$ while food $\mathrm{B}$ rejects $120 \mathrm{~kg}$ / tonne of fish produced.

These improvements were initially allowed by the improvement of feed production techniques, in particular by the use of extrusion processes from 1984 [14]. These techniques made it possible to produce foods with better physical stability, " increase the quantity of lipids replacing part of the proteins, improve the digestibility of carbohydrates while reducing their quantity to what is strictly necessary for cohesion of the granules this made it possible the production of high energy diet with better feed efficiency and producing less waste.

The modeling between the density and the physicochemical elements studied $\left(\mathrm{PO}_{4}^{3-}, \mathrm{NH}_{4}{ }^{+}, \mathrm{NO}_{2}^{-}, \mathrm{NO}_{3}{ }^{-}, \mathrm{SM}\right.$ and $\mathrm{COD}$ ) of two formulations (F1 and F2) made by mathematical equations allowed us to highlight the maximum densities which are respectively of $\rho \mathrm{B}=$ $176.35 \mathrm{Kg} / \mathrm{m}^{3}, \rho \mathrm{F} 1=175 \mathrm{Kg} / \mathrm{m}^{3}$ and $\rho \mathrm{F} 2=237.09 \mathrm{Kg} /$ $\mathrm{m}^{3}$ for the three feeds B, F1 and F2.

Our results confirm that formulation F2 encompasses all growth performance criteria with a much lower conversion index of an average of $\mathrm{IC}_{\mathrm{F} 2}=0.73$ compared to feed $\mathrm{F} 1$ and $\mathrm{B}$ and that the maximum density reached $\rho \mathrm{F} 2=237,09 \mathrm{Kg} / \mathrm{m}^{3}$ has no negative effects on the water quality of Oued Oum Er-Rbia.

\section{Conclusion}

The monitoring of the growth of rainbow trout fed with the two formulations $F 1$ and $F 2$ is the result of the comparative test of the three feeds fish tested (A, B and $\mathrm{C})$. The results of the comparative test show that feed $\mathrm{B}$ is the reference feed for the manufacture of two feeds (F1 and F2) having the same biochemical composition ( $41 \%$ of proteins and $24 \%$ of lipids) with percentages of animal proteins and different plants. Our results show that the F2 formulation, containing $60 \%$ of animal proteins, gives great growth, knowing that the difference in growth between two formulations F1 and F2 is not significant. To make their production profitable, fish farmers intensify their production, which increases releases into the environment. In our study, the high inlet flow allowed the water in the basins to be diluted. Only phosphorus can have a negative impact and lead to eutrophication of sensitive environments. Optimal management of fish feed is the most effective way to reduce phosphorus releases into the environment. However, in sensitive environments, further treatment may be necessary such as a substitution of phosphorus provided by fishmeal with an animal or vegetable ingredient less rich in phosphorus.

\section{References}

1. Ouellet G., 1999. Les rejets des stations piscicoles et leurs impacts environnementaux. Ministère de l'Agriculture, des Pêcheries et de l'Alimentation, $45 \mathrm{p}$.

2. Morin R., 2012. Qualité de l'eau requise pour l'élevage des salmonidés. Document d'information DADD-14. Ministère de l'Agriculture, des Pêcheries et de l'Alimentation. 25 p. http://www.mapaq.gouv.qc.ca/Fr/Peche

3. Verdegem M.C.J, Eding E.H., Rooy van J.M., Verreth, J.A.A.,1999. Comparison of effluents from pond and recirculating production systems receiving formulated diets. W orld Aquaculture: 28-32.

4. Agreste., 2008. Résultats nationaux sur les matières premières de l'alimentation animale 2006.Agreste chiffres et données agroalimentaires 155.

5. Regost C., Arzel J., Kaushik S.J., 1999. Partial or total replacement of fish meal by corn gluten meal in diet for turbot (Psetta maxima).Aquaculture, 180, 99-117.

6. Burel C., Boujard T., Escaffre A.M., Kaushik S.J., Boeuf G., Mol K.A., Van Der Geyten S., Kühn E.R., 2000. Dietary low-glucosinolate rapeseed meal 
affects thyroid status and nutrient utilization in rainbow trout (Oncorhynchus mykiss). Br. J. Nutr., 83, 653-664.

7. Kaushik S.J., Oliva-teles A., 1984. Effect of digestible energy on nitrogen and energy balance in rainbowtrout, " Aquaculture, 50, 89-101.

8. Polakof S., Panserat S., Soengas J., Moon T.W., 2012. Glucose metabolism in fish: a review. J. Comp. Physiol. B, vol.182, pp.1015-1045.

9. Flimlin G., Suigiura S., Ferraris., P R., 2003. Examining phosphorus in effluents from rainbow trout (Onchorynkiss Mykiss) .Aquaculture, rutgure cooperative extension bulletin (E287), p.6.(2003).

10. Boujard, T., Vallée, F., Vachot, C., 1999. Évaluation des rejets d'origine nutritionnelle de truiticultures par la méthode des bilans, comparaison avec les flux sortants. Dossier de l'environnement de l'INRA $n^{\circ} 26$.

11. Jatteau P., Kempf M., Petit J., 1999. Modalités de prise en compte des causes et effets lors des études d'impact. INRA, Paris. in : Environnement et aquaculture : $\mathrm{t} 1$ Aspects techniques et économiques, PETIT J. : 87-92.

12. Burel C., Médale F., 2014. Protein source in animalfeed. Guide d'utilisation des protéines d'origine végétale en aquaculture. OCL, Aquapole INRA.21(4).

13. Enell, M., 1987. Environmental impact of cage fish farming with special refrence to phosphorus and nitrogen lodings, swedish environmental research institute (IVL), P.O. Box 21060, 5-100 31 stockholm, sweden

14. Johnsen, F., Wandsvik, A., 1991. The impact of high energy diets on pollution control in the fish farming industry. In : Nutritional strategies and Aquaculture waste. C.B. Cowey and C. Y. Cho (Eds.), 51-63. 